\title{
SPOTLIGHT ON ARTS GRANTMAKING IN CALIFORNIA
}

The Foundation Center's mission is to strengthen the nonprofit sector by advancing knowledge about U.S. philanthropy. In this report, we shine a spotlight on the arts community in California.

In conjunction with the Foundation Center's Funding for the Arts month, the Foundation Center-San Francisco compiled this report on arts funding in California. It includes the results of a brief survey of California's arts grantmakers and arts organizations as well as statistical information based on the Center's annual grants sample.

\section{RESULTS OF OUR 2009 SURVEY OF ARTS GRANTMAKERS AND ARTS ORGANIZATIONS}

\section{Areas of Interest and Types of Support}

California enjoys a highly diverse array of arts organizations and activities, with great emphasis placed by grantmakers and grantees on arts education, the visual arts, and music. Sixty-six grantmakers and 194 arts organizations responded to the survey (see About the Survey on page 2). As shown in Figure 1, arts education was the top program interest of both grantmakers and grantees responding to our survey.

When asked about the types of support needed, 85 percent of arts groups put general operating support at the top of the list. However, only 55 percent of grantmakers said they provide general operating support for arts organizations. There was a significant disparity between the two groups surveyed in the areas of program development, endowments, and performance/ production costs. Thirty-one percent of arts organizations indicated a need for program development funds, yet 55 percent of grantmakers stated they provided that type of support.

Similarly, 44 percent of arts organizations indicated a need for performance/production funding, while 51 percent of grantmakers said they funded performance and production costs. Conversely, 21 percent of arts organizations expressed a need for endowment funds while only 6 percent of grantmakers provided endowment grants (Figure 2).
FIGURE 1.

Program Interests of Grantmakers and Arts Organizations

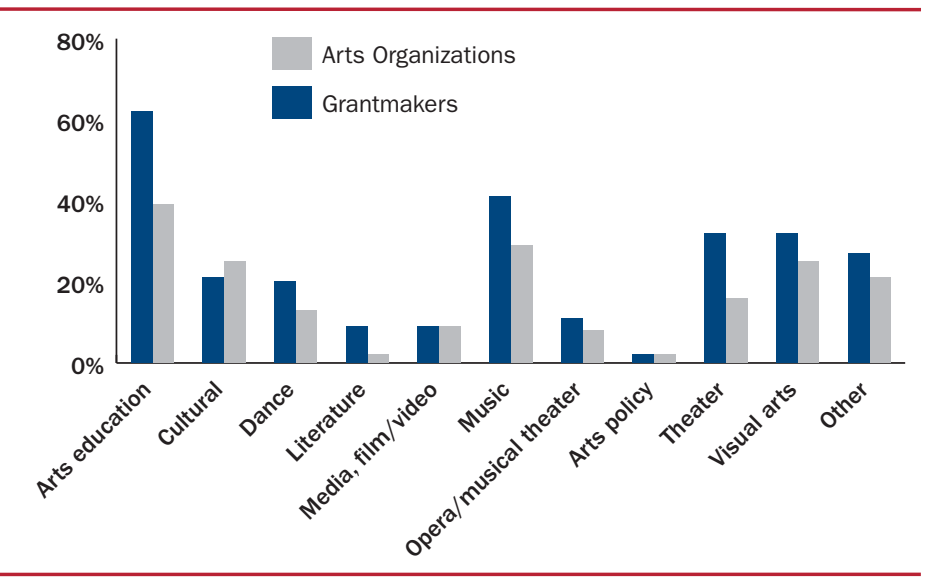

FIGURE 2.

Types of Support Grantmakers Award Compared to What Arts Groups Say They Need Most

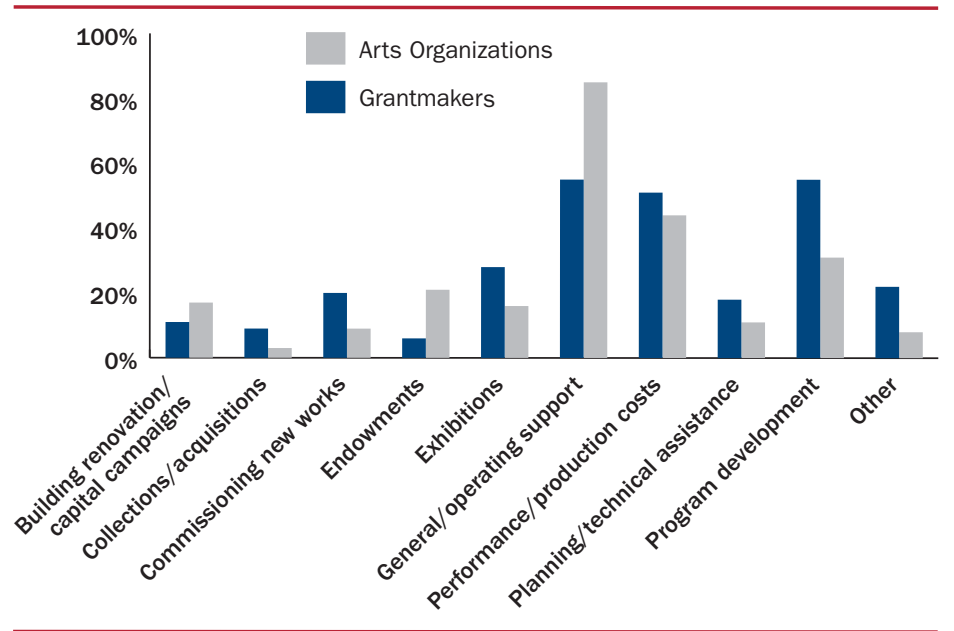


FIGURE 3.

What Changes Has Your Organization Undergone
Because of the Economic Downturn?

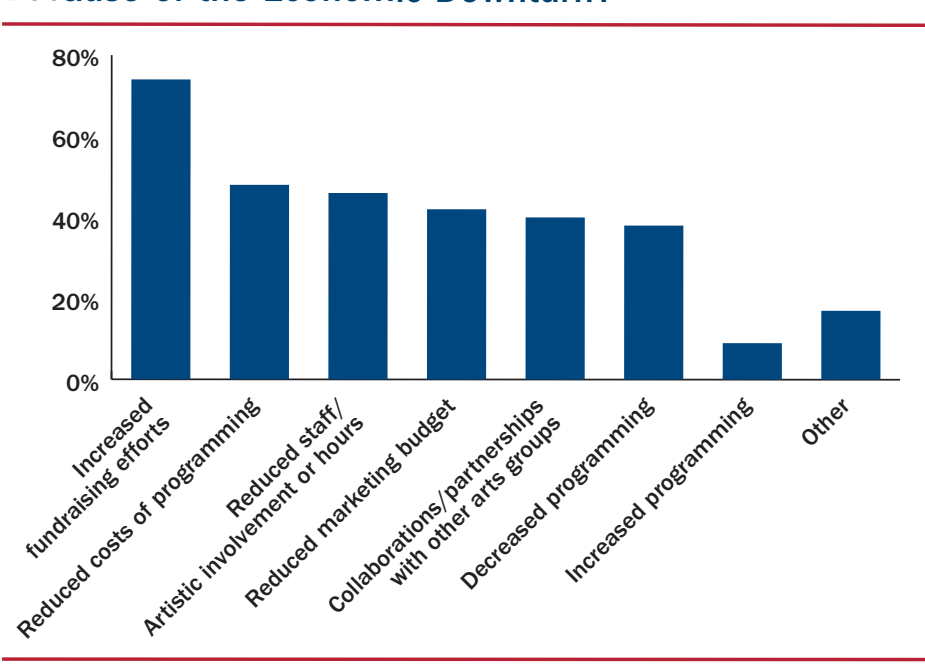

Respondents could select multiple categories.

FIGURE 4.

How Is the Economic Downturn Affecting Your Grantmaking?

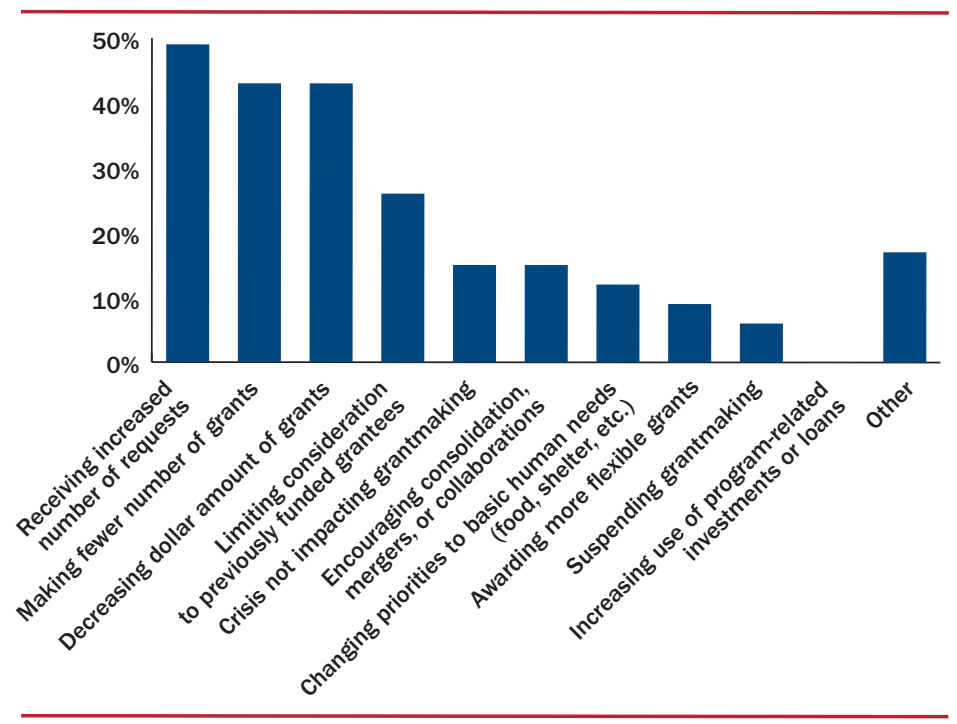

Respondents could select multiple categories.

\section{Effects of the Economic Crisis}

Most arts groups responding to our survey had modest budgets. Fifty-three percent of groups surveyed had operating budgets under $\$ 500,000$. Twenty-one percent had budgets between $\$ 500,000$ and $\$ 1$ million, and 20 percent had budgets between $\$ 1$ million and $\$ 5$ million. The remainder had budgets over $\$ 5$ million. Most organizations, regardless of budget size, were not greatly dependent on foundation and corporate support for annual income. More than 60 percent of arts organizations responding to the survey said foundation and corporate support represented 25 percent or less of their annual contributed income, and only 12 percent reported that foundation and corporate support comprised more than half of their donated income.

When asked what changes their organizations had undergone because of the economic downturn many groups indicated significant impact. Seventy-four percent of respondents said they had increased their fundraising efforts, 48 percent had reduced programming costs, and 46 percent had reduced staff/artistic involvement or hours (Figure 3).

A similar question was posed to grantmakers about the impact of the economy on their grantmaking. Among survey respondents, 49 percent reported an increase in the number of funding requests, and 43 percent said that they were both making fewer grants and decreasing the dollar amount of the grants given (Figure 4).

\section{Outlook for Funding}

When asked if they thought their foundation funding in 2009 would increase, decrease, or remain the same as in 2008, 23 percent of arts groups expected a moderate decrease in foundation funding, 19 percent expected a slight increase, and 15 percent thought it would remain the same (Figure 5).

By comparison, 32 percent of grantmakers expected their giving to arts organizations in 2009 to remain the same, 20 percent expected a moderate decrease, and 15 percent a slight decrease (Figure 5).

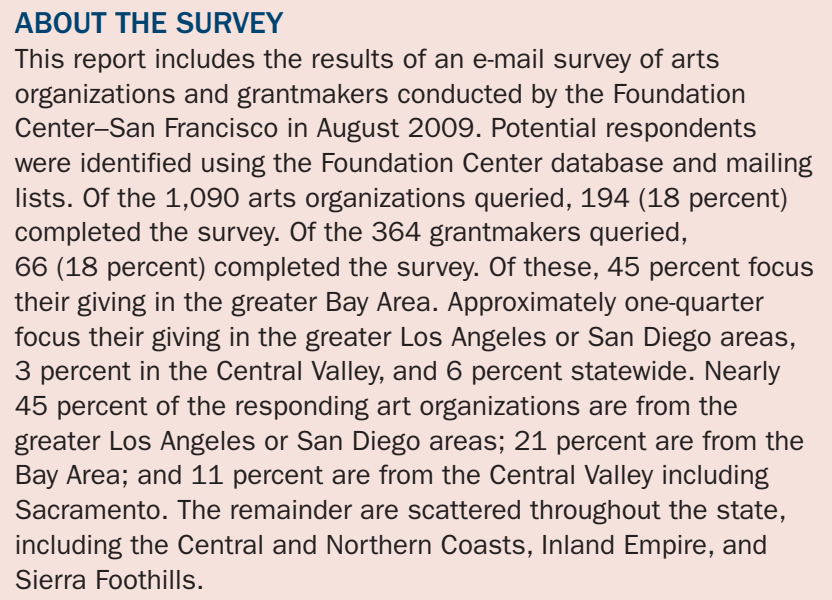
organizations and grantmakers conducted by the Foundation Center-San Francisco in August 2009. Potential respondents were identified using the Foundation Center database and mailing lists. Of the 1,090 arts organizations queried, 194 (18 percent) completed the survey. Of the 364 grantmakers queried, 66 (18 percent) completed the survey. Of these, 45 percent focus their giving in the greater Bay Area. Approximately one-quarter focus their giving in the greater Los Angeles or San Diego areas, 3 percent in the Central Valley, and 6 percent statewide. Nearly 45 percent of the responding art organizations are from the greater Los Angeles or San Diego areas; 21 percent are from the Bay Area; and 11 percent are from the Central Valley including Sacramento. The remainder are scattered throughout the state, including the Central and Northern Coasts, Inland Empire, and Sierra Foothills. 
When asked their opinion about the future of arts funding in California, grantmakers' responses reflected the uncertainty of these economic times; 56 percent were concerned, 14 percent were pessimistic, while only 14 percent were optimistic.

\section{Advice for Grantmakers from Arts Organizations}

We gave the arts groups who responded to the survey the opportunity to give open-ended advice to grantmakers about strategies they would like to see grantmakers employ to best assist them in overcoming the challenges they are facing today. The most requested assistance can be grouped into the following four categories: providing more funding for capacity building, especially technical assistance with collaborations/mergers and restructuring (20 percent); assisting organizations with networking and introductions to other potential donors (8 percent); providing more funding dedicated to general support (8 percent) and easing the grantseeking process either by streamlining the application process or lifting grant restrictions that are tied to existing grants (7 percent).

Below are representative comments:

- "Sponsor professional advisors to help us manage our organization."

- "Provide workshops and consultations, share resources and information."

- "Reduce restrictions on funding to let practitioners apply funds the best way for their organization."

- "Give flexibility to organizations by giving general operating grants instead of program-specific grants. Provide multi-year grants so nonprofits have a better sense of funding beyond one year."

FIGURE 5.

Grantmakers' vs. Arts Organizations' Expectations of Foundation Giving in 2009

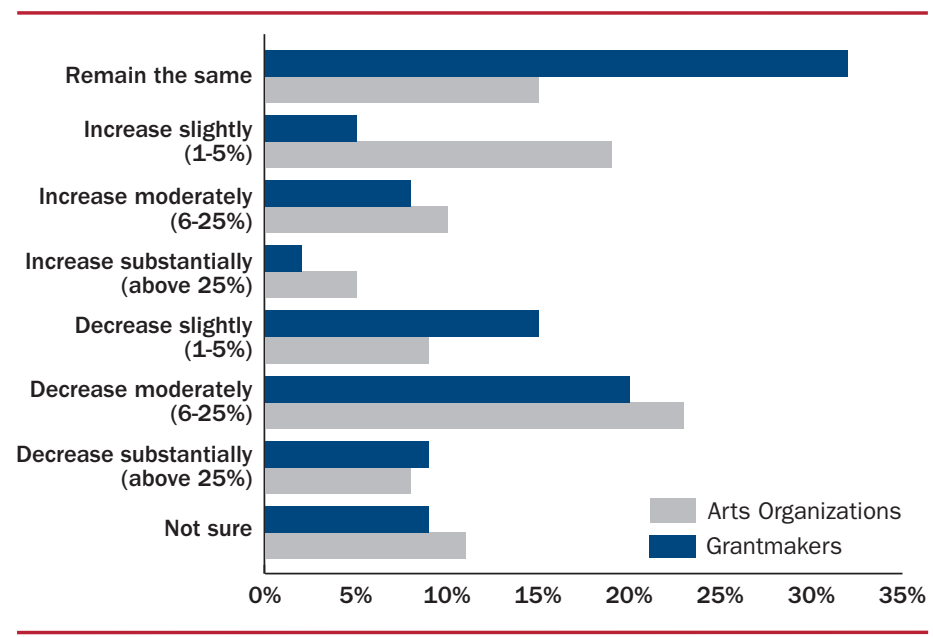

\section{Funding for Individuals}

Fifteen percent of respondents to the grantmaker survey reported that they made grants to individuals, with most support given through awards, prizes, and competitions. Sixty percent of arts organizations surveyed reported providing support to individual artists. Nearly half of these provided assistance in expanding audiences or the number of clients. Almost 40 percent supported artists through awards, prizes, and competitions, and through the commissioning of new works.

\section{ARTS GRANTS COMPARED TO ALL GRANTS IN THE SAMPLE}

\section{About the Sample}

The definition of arts and culture used for this report is based on the National Taxonomy of Exempt Entities and encompasses funding for the performing arts, museums, visual arts, multidisciplinary arts, media and communications, humanities, and historical societies/historical preservation. The data are based on arts grants of $\$ 10,000$ or more awarded by 1,339 of the nation's largest foundations, 118 of which were located in California.

\section{The Arts Share of All Grant Dollars}

In 2007, foundations included in the Center's annual grants sample provided 21,527 grants totaling $\$ 2.3$ billion for arts and culture on a national basis. Giving for the arts to Californiabased recipients totaled nearly $\$ 333$ million. This represented 12 percent of all grant dollars awarded to California recipients in 2007 (Figure 6).

FIGURE 6.

\section{Percent of Grant Dollars for California by Field of Giving, 2007}

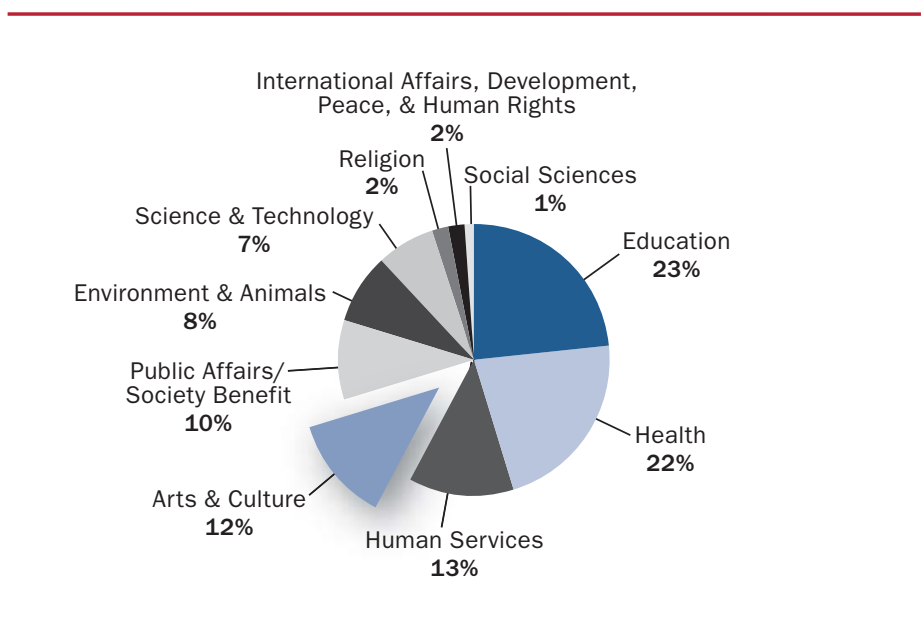

Source: The Foundation Center, 2009 , based on all grants of $\$ 10,000$ or more awarded by a sample of 1,339 larger foundations. 
TABLE 1.

10 Largest Arts, Culture, and Media Funders for California, 2007

\begin{tabular}{|c|c|c|c|c|c|}
\hline Rank Foundation & State & $\begin{array}{l}\text { Arts Grant } \\
\text { Dollars for } \\
\text { California }\end{array}$ & $\begin{array}{l}\text { No. of Arts } \\
\text { Grants for } \\
\text { California }\end{array}$ & Arts and Culture Focus Areas in California & $\begin{array}{l}\text { Response to } \\
\text { Economic Crisis }\end{array}$ \\
\hline $\begin{array}{l}\text { 1. Eli \& Edythe Broad } \\
\text { Foundation }\end{array}$ & $\mathrm{CA}$ & $\$ 30,365,220$ & 12 & $\begin{array}{l}\text { Fostering public appreciation of contemporary art by increasing } \\
\text { access for audiences worldwide. }\end{array}$ & $\begin{array}{l}\text { Founder Eli Broad has } \\
\text { donated } \$ 18 \text { million } \\
\text { more to the foundation } \\
\text { than he did in } 2007 \text {. }\end{array}$ \\
\hline $\begin{array}{l}\text { 2. Annenberg } \\
\text { Foundation }^{1}\end{array}$ & PA & $30,302,617$ & 68 & $\begin{array}{l}\text { The foundation has supported exhibitions, programming and } \\
\text { publications at art institutions of all sizes, from the Museum } \\
\text { of Modern Art in New York to the Hammer Museum in } \\
\text { Los Angeles. The foundation has made significant investments } \\
\text { such as a } \$ 23 \text { million grant to the Los Angeles County } \\
\text { Museum of Art for acquisition of The Marjorie and Leonard } \\
\text { Vernon Collection, a comprehensive history of photography } \\
\text { and collection of masterworks from the 19th and } \\
\text { 20th centuries. }\end{array}$ & $\begin{array}{l}\text { Expects a decline in the } \\
\text { overall number and size } \\
\text { of grants awarded in } \\
2009 \text {. }\end{array}$ \\
\hline 3. Ahmanson Foundation & $\mathrm{CA}$ & $23,824,420$ & 59 & Funds arts and humanities projects in Los Angeles county. & $\mathrm{N} / \mathrm{A}$ \\
\hline 4. Skirball Foundation & NY & $22,740,666$ & 12 & Funds Skirball Cultural Center and performing arts groups. & $\mathrm{N} / \mathrm{A}$ \\
\hline $\begin{array}{l}\text { 5. James Irvine } \\
\text { Foundation }\end{array}$ & $\mathrm{CA}$ & $20,627,000$ & 134 & $\begin{array}{l}\text { The goal of the foundation's arts program is to promote a } \\
\text { vibrant and inclusive artistic and cultural environment in } \\
\text { California. The foundation believes that a healthy arts system } \\
\text { in today's environment should consist of arts organizations } \\
\text { that support the creation and presentation of art, that connect } \\
\text { art to diverse communities, that explore artistic innovation and } \\
\text { risk-taking, and that provide leadership for the field and in } \\
\text { their communities. Irvine organizes its arts grantmaking along } \\
\text { the following priority areas: 1) Artistic creativity: Promote the } \\
\text { creation and reinterpretation of art, infusing the arts field with } \\
\text { new ideas and methods of creative expression. 2) Connection } \\
\text { through cultural participation: Support the active engagement } \\
\text { of Californians from all socioeconomic and ethnic backgrounds } \\
\text { with quality art from a variety of sources and cultures. 3) Arts } \\
\text { leadership: Foster an environment in which arts and culture } \\
\text { flourish in California through support to the state's largest } \\
\text { premier cultural institutions and to leading arts organizations } \\
\text { in the non-metropolitan areas of California. }\end{array}$ & $\begin{array}{l}\text { Created the Fund for } \\
\text { Financial Restructuring. } \\
\text { Through a competitive } \\
\text { application process, } \\
\text { it will provide support } \\
\text { to leaders and } \\
\text { organizations that have } \\
\text { already initiated internal } \\
\text { planning processes to } \\
\text { determine how best } \\
\text { to adapt. }\end{array}$ \\
\hline $\begin{array}{l}\text { 6. William and Flora } \\
\text { Hewlett Foundation }\end{array}$ & $\mathrm{CA}$ & $18,718,600$ & 109 & $\begin{array}{l}\text { The Performing Arts Program provides multi-year general } \\
\text { operating support to hundreds of Northern California } \\
\text { organizations in theater, dance, music, opera, film and media, } \\
\text { musical theater, and arts education. The program's grants are } \\
\text { designed to stimulate increased access to and participation in } \\
\text { the arts; increase exposure to and understanding of diverse } \\
\text { cultural expressions; enhance opportunities for creative } \\
\text { expression for both artists and audiences; and to promote the } \\
\text { long-term health of arts organizations. }\end{array}$ & $\begin{array}{l}\text { Will honor grant } \\
\text { commitments made in } \\
2008 \text { and previous } \\
\text { years, though the dollar } \\
\text { amount of its overall } \\
\text { grantmaking is likely to } \\
\text { be down. }\end{array}$ \\
\hline $\begin{array}{l}\text { 7. Chartwell Charitable } \\
\text { Foundation }\end{array}$ & $\mathrm{CA}$ & $12,308,000$ & 41 & $\begin{array}{l}\text { Funds performing and visual arts organizations, museums, and } \\
\text { public television in Los Angeles county. }\end{array}$ & $\mathrm{N} / \mathrm{A}$ \\
\hline $\begin{array}{l}\text { 8. Walt and Lilly Disney } \\
\text { Foundation }\end{array}$ & $\mathrm{CA}$ & $12,056,000$ & 3 & $\begin{array}{l}\text { Funds the Walt Disney Family Museum and the Los Angeles } \\
\text { Philharmonic. }\end{array}$ & $\mathrm{N} / \mathrm{A}$ \\
\hline 9. Ford Foundation & NY & $10,344,500$ & 19 & $\begin{array}{l}\text { Within the Freedom of Expression program the foundation } \\
\text { supports examples of } 21 \text { st-century arts leadership who share } \\
\text { knowledge, build capacity and serve as models of artistic } \\
\text { innovation, cultural collaboration, inclusion and social } \\
\text { partnership. Supports the development of a global network of } \\
\text { "sites of conscience" central to public exploration of memory } \\
\text { and history. Helps create a pipeline of high-quality media } \\
\text { content; strengthen the technology and distribution systems } \\
\text { that allow people to access and contribute to this material; } \\
\text { and boost public discussion and research about the ways in } \\
\text { which media can better engage and inform all citizens. }\end{array}$ & $\begin{array}{l}\text { Will increase the } \\
\text { percentage of its } \\
\text { endowment that is paid } \\
\text { out in grants in } 2009 \\
\text { and } 2010 .\end{array}$ \\
\hline $\begin{array}{l}\text { 10. Silicon Valley } \\
\text { Community } \\
\text { Foundation }\end{array}$ & $\mathrm{CA}$ & $9,352,492$ & 303 & $\begin{array}{l}\text { Encourages the creation and appreciation of professional } \\
\text { quality artistic works that reflect the region's diverse cultural } \\
\text { communities through the Donor Circle for the Arts. }\end{array}$ & $\begin{array}{l}\text { Will maintain } \\
\text { grantmaking of } \\
\$ 8 \text { million from its } \\
\text { endowment in } 2009 \text {. }\end{array}$ \\
\hline
\end{tabular}


This percentage was lower than the arts' share in 2006 and the 13.2 percent average share for the past decade. From 1997 through 2007, the arts share of all foundation grant dollars in California ranged from a low of 9.9 percent in 2001 to a high of 16.9 percent in 1998.

\section{Primary Purpose}

Funding for museums and for the performing arts combined accounted for nearly 60 percent of all giving for the arts in California in 2007, with the performing arts at 32 percent and museums at 27 (Figure 7).

FIGURE 7.

\section{Arts and Culture Subfields Giving for California, 2007}

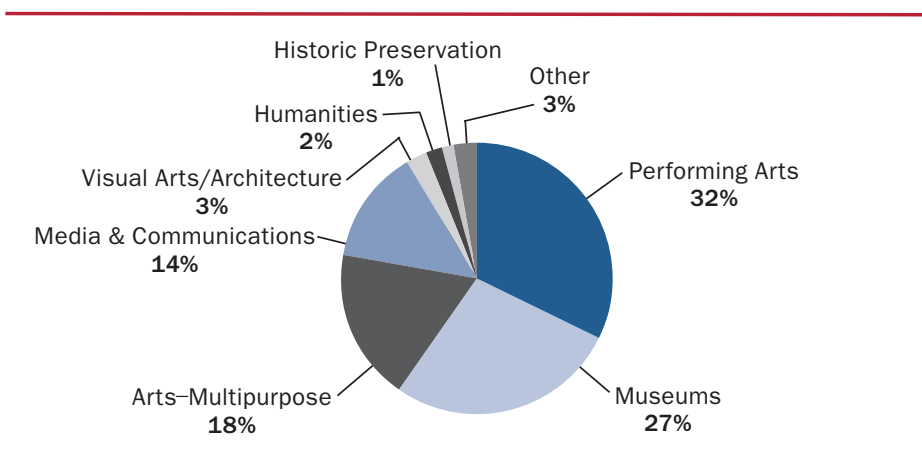

Source: The Foundation Center, 2009 , based on all grants of $\$ 10,000$ or more awarded by a sample of 1,339 larger foundations.

Source for all data: The Foundation Center.

Spotlight on Arts Grantmaking in California is available at foundationcenter.org/gainknowledge.

For more information, contact Janet Camarena, director, the Foundation Center-San Francisco, at (415) 397-0902 x100, or e-mail jfc@foundationcenter.org.

\section{Types of Support}

The three largest categories of support tracked by the Foundation Center are program support, capital support, and general operating support. See Figure 8 for a comparison of these three categories of dollars for arts and culture versus grant dollars for other major foundation subject areas.

Program support accounted for the largest percentage of arts grants dollars in 2007 (41.3 percent). General operating support accounted for 35 percent of arts grants dollars. This represents the largest portion of giving for general operating support among major fields of foundation support (Figure 8).

FIGURE 8.

General, Program, and Capital Support Grant Dollars for California by Major Field of Giving, 2007

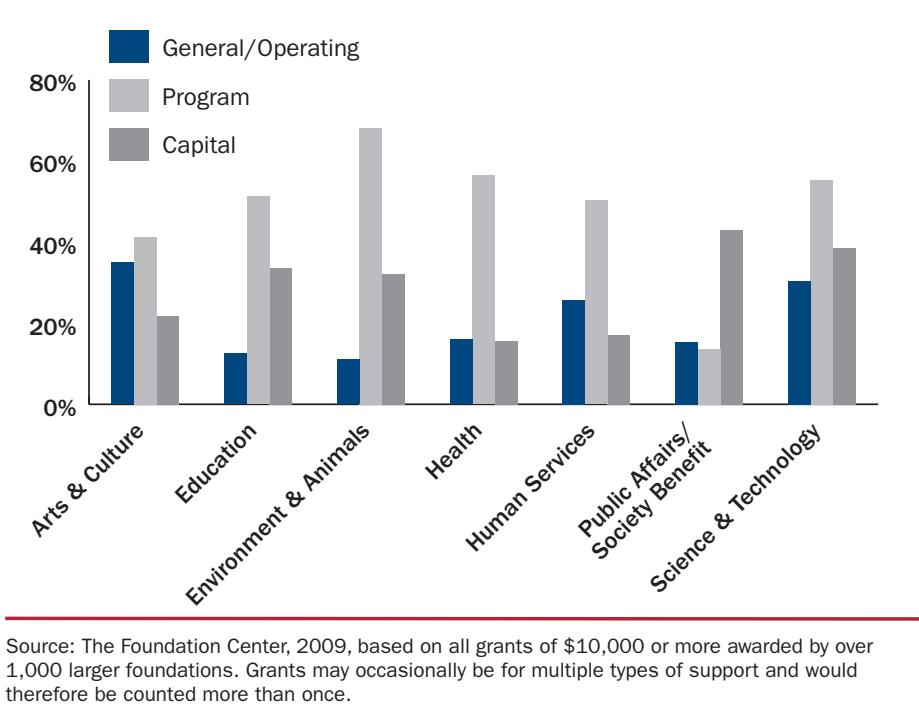

